\title{
Variability and relationship of six Indonesian shallots (Allium cepa var. ascalonicum ) cultivars based on amino acid profiles and fried shallot's sensory characteristics
}

\author{
OLIVIA YOFANANDA ${ }^{1}$, SOBIR ${ }^{2}$, C. HANNY WIJAYA ${ }^{1, \boldsymbol{\nu}}$, HANIFAH NURYANI LIOE ${ }^{1}$ \\ ${ }^{1}$ Department of Food Science and Technology, Faculty of Agricultural Engineering and Technology, Institut Pertanian Bogor. Jl. Kamfer, IPB Darmaga \\ Campus, Bogor 16680, West Java, Indonesia. Tel./fax.: +62-251-8626725, `email: channywijaya@apps.ipb.ac.id \\ ${ }^{2}$ Department of Agronomy and Horticulture, Faculty of Agriculture, Institut Pertanian Bogor. Jl. Kamfer, IPB Darmaga Campus, Bogor 16680, West \\ Java, Indonesia
}

Manuscript received: 16 April 2021. Revision accepted: 20 July 2021

\begin{abstract}
Yofananda O, Sobir, Wijaya CH, Lioe HN. 2021. Variability and relationship of six Indonesian shallots (Allium cepa var. ascalonicum) cultivars based on amino acid profiles and fried shallot's sensory characteristics. Biodiversitas 22: 3327-3332. Shallot is an essential spice in the daily menu and processed food due to its unique flavor. Therefore information regarding the correlated compounds responsible for flavor in several cultivars of shallot will be important to elucidate. Since the amino acids profile is a key component of flavor character, this study aimed to determine the variability of amino acid profiles among six shallot cultivars related to fried shallot's sensory characteristics. The six shallot cultivars were Bima Brebes, Bauji, Batu Ijo, Tajuk, Super Philip, and Rubaru. The shallot bulb was cultivated in the same area. The bulb size was analyzed using an analytical balance, the amino acids profile was analyzed using HPLC instrument, and sensory characteristics of fried shallots were analyzed using the rate-all-that-apply descriptive method. The result showed that the shallots contained a high content of glutamic acid, arginine, and aspartic acid. Based on fresh weight, Batu Ijo was significantly different than the other cultivars which comprised Tajuk, Rubaru, Bauji, Super Philip and Bima Brebes. Clustering based on amino acid profiles of the fresh bulb, they were divided into three groups. The first group consisted only Bauji, and the second group consisted of Rubaru, Batu Ijo, Super Philip and Tajuk, the third group was only Bima Brebes. Based on the sensory characteristics of fried shallots, they were divided into three groups. The first group comprised of Bauji and Tajuk, the second group comprised of Rubaru alone, and the third group comprised of Batu Ijo, Super Philip, and Bima Brebes. The Pearson correlation analysis showed that L-phenylalanine, L-arginine, and glycine have a significant positive correlation with a sweet taste of fried shallot, indicated that amino acids profile is an important parameter for shallot flavor.
\end{abstract}

Keywords: amino acid, biodiversity, clustering, flavor, fried shallots

\section{INTRODUCTION}

Shallot is widely used as a cooking spice, medicine, and commercially processed product. As part of the Allium family, fresh shallots have a strong flavor pungency character. The precursor flavor of Alliums is alk(en)ylcysteine-sulfoxide. In other Allium family, such as garlic, it was found that this commodity could improve the taste when added to the umami solution (Ueda et al. 1990), such as Chinese soup and chicken broth. Roasted garlic as processed Allium, has also been found to improve taste (Wakamatsu et al. 2016). Besides being added in the fresh form to be a cooking spice, fried shallots are also marketed as a commercial product. The distinctive taste of fried shallots makes it an additional ingredient in the food. Commercially, fried shallots are sold by providing cultivar brandings such as Bima Brebes and Sumenep fried shallots. The distinctive flavor formed by each cultivar may be the reason for the branding of shallot cultivars.

The diversity of shallots has been widely studied based on morphological markers (Sari et al. 2017; Major et al. 2018; Herlina et al. 2019a), volatile profiles (Galingging et al. 2018), and genetic markers (Herlina et al. 2019b). The characteristics of fried shallots desired by consumers' have high intensity of savory taste, fragrant sulfury aroma, and crispness. In contrast, bitter taste and rancid aroma are undesirable attributes of the product (Yofananda et al. 2020). The sensory characteristics that appear in a product are closely related to the chemical composition of a commodity, this has been studied in almond (Franklin and Mitchell 2019) and mango (Sung et al. 2019). In the production process of fried shallots through the frying process, the Maillard reaction is one of the most common reactions that occurred (Chang et al. 2020). This reaction occurs due to high temperatures involving amino acids and reducing sugars contained in the raw material (Chang et al. 2020). The content of sugars, and ten amino acids in shallots have been studied by Soininen et al. (2014). Vu et al. (2013) studied the content of sugar, phenolic, quercetin and precursor flavor of several shallot landraces in Vietnam and six countries. Ferioli and D'Antuono (2015) also studied the composition of phenolic and flavor components of shallot from Italy, the composition of fructose, glucose, sucrose, fructan, flavonoid, and several S-alk(en)yl-Lcysteine sulfoxides in several cultivars of Indonesian shallots have been studied by Ariyanti et al. (2018). In addition, Abdelrahman et al. (2020) also studied the amino acid composition of several Indonesian shallots that were 
compared with onions. However, the diversity of Indonesian shallots based on their amino acids and their correlation to sensory characteristics of the fried product has not been reported.

Studies on the use of suitable cultivars for a product need to be carried out to produce a higher quality product and preferable by the consumers. Recently, there has been no report on what cultivar is suitable for being fried shallots. The potential of shallot cultivars can be determined using sensory evaluation, one of which is the rate-all-that-apply descriptive sensory method to know the sensory characteristics of fried shallots of certain cultivars. Amino acids as compounds expected to affect the flavor variability of fried shallots also need to be studied. The diversity of a commodity is usually studied based on morphology and DNA analysis. Therefore, studies based on chemical compounds to a specific use will be scientifically advantageous. This study aimed to identify the diversity of six shallot cultivars based on their amino acid profiles and their sensory characteristics of fried shallots, and determine the correlation between amino acid profiles of fresh shallots and sensory characteristics of fried shallots.

\section{MATERIALS AND METHODS}

\section{Plant materials}

In this study, six shallot cultivars were selected, namely Bima Brebes, Bauji, Batu Ijo, Tajuk, Super Philip, and Rubaru. The Rubaru cultivar was chosen because this cultivar is renowned for being as raw material of superior fried shallots. Commercially, Rubaru cultivar is renowned as Sumenep, and due to customer acceptance, Sumenep fried shallot has already been marketed in supermarkets. Another cultivar that is commonly used as a fried shallot brand is the Bima Brebes cultivar. On the other hand, Bauji, Batu Ijo, Tajuk, and Super Philip cultivars have never been reported as raw materials for fried shallots.

Six cultivars of shallot used in this study were cultivated from the middle of September to the middle of November 2019. We obtained the seeds of three cultivars (Bima Brebes, Batu Ijo, and Rubaru) from a local farmer breeder at Majalengka, West Java, Indonesia. In addition, we obtained the seeds of two cultivars (Tajuk and Bauji) from a local farmer breeder at Nganjuk, East Java, Indonesia. And, the seeds of Super Philip cultivar were obtained from a local farmer breeder at Cirebon, West Java, Indonesia. Furthermore, the shallots seeds were planted in the same location for about 60 days. The planting area was at the Pasir Kuda Experimental Garden, IPB University, Bogor, Indonesia.

\section{Procedures}

\section{Bulb analysis}

The fresh weight of each shallot bulb that have been dried for two weeks after harvest was measured using an analytical balance.

\section{Amino acid analysis of fresh bulb}

The amino acid analysis followed the manual procedures of Waters Corporation (2012) method. First, the shallots, which have been sliced as much as 0.1-1.0 grams, were put into a $20 \mathrm{~mL}$ vial headspace then hydrolyzed using $5 \mathrm{~mL} 6 \mathrm{~N} \mathrm{HCl}$ at $110{ }^{\circ} \mathrm{C}$ for 22 hours. Next, the sample was added with aquabidest up to $50 \mathrm{~mL}$ in a volumetric flask. The homogenized solution was then filtered with a $0.2 \mu \mathrm{m}$ syringe filter to obtain the filtrate. The filtrate obtained was taken $500 \mu \mathrm{L}$ and added with 40 $\mu \mathrm{L}$ of internal standard alpha aminobutyric acid (AABA) and $460 \mu \mathrm{L}$ of distilled water to be derivatized. A total of $10 \mu \mathrm{L}$ of the mixture was added with $70 \mu \mathrm{L}$ of AccQ-Fluor borate buffer and $20 \mu \mathrm{L}$ of AccQ-Tag Ultra reagent (6aminoquinolyl-N-hydroxy succinimidyl carbamate (ACQ)). The mixture was then incubated at $55{ }^{\circ} \mathrm{C}$ for 10 minutes. Finally, the sample is ready to be injected into the HPLC column. Extracted samples were injected into UPLCPDAD (Water Corporation, USA) with the following conditions: injection volume was $10 \mu \mathrm{L}$, column type was AccQ-Tag Ultra C-18 $(2.1 \times 100 \mathrm{~mm})$, mobile phase: solvent A was Eluent AccQ-Taq Ultra from water, solvent B was $10 \%$ mobile phase D, solvent C was Milli-Q water, solvent D was Eluent AccQ-Taq Ultra from Waters. Photodiode array (PDA) detector with a UV wavelength of $260 \mathrm{~nm}$ was used as a detector.

Sensory characterization of fried shallots from six cultivars

Fresh shallots from the six cultivars were processed into fried shallots. The production process of fried shallot was carried out based on the interviews at Semarang traditional market as follows: the tubers were sliced with a knife, followed by washing using $2 \%$ salt in water (w/w sample). Slices were done until the thickness of the shallots was 1-2 $\mathrm{mm}$. Then, the slices were fried with palm cooking oil at 105-110 ${ }^{\circ} \mathrm{C}$ for 4-5 minutes until the color turned brownish-yellow.

The fried shallots were tested for sensory evaluation using the descriptive sensory method, rate-all-that-apply (RATA). The attributes used were obtained from the previous study (Yofananda et al. 2020), namely fragrant sulfury aroma, sweet aroma, rancid aroma, savory taste, sweet taste, salty taste and bitter taste. Fried shallots from each cultivar were packaged and served as much as 1 gram to the panelists. Panelists who took part in the test were untrained, consisted of undergraduate students, graduate students, and employees of the IPB University. A brief explanation was carried out to introduce the panelists to measuring the intensity of each sensory attribute. Then, panelists were asked to assess each fried shallot sample's intensity of the sensory attributes on the questionnaire sheet that had been given (Waehrens et al. 2016). The scale used for intensity measurement is a numeric scale with 6 numeric points, 0 marks as undetected, 1- detected very weak to 5-detected very strong. Each fried shallot was served randomly with three digits coded. Panelists were asked to consume palate-cleansing (water and crackers) to neutralize the sensory senses between each sample. 


\section{Data analysis}

Data obtained from bulb fresh weight and amino acid profiling were analyzed using one-way analysis of variance (ANOVA) and Tukey post hoc test using SPSS 22 software (UBM, USA). We analyzed six Indonesian shallot cultivar clustering based on amino acid profile and sensory characteristics of fried shallots using PBSTAT 2.1.1 (https://apps.pbstat.com/reports/pbstat-cl/). The correlation of the amino acid profile of fresh shallots with the sensory profile of fried shallots was analyzed using Pearson's correlation using SPSS 22 software (UBM, USA).

\section{RESULTS AND DISCUSSION}

\section{The amino acid composition of six shallot cultivars}

The amino acid composition was analyzed using an HPLC instrument, and the result is shown in Figure 1. Amino acids observed in this study were L-serine, Lglutamic acid, L-phenylalanine, L-isoleucine, L-valine, Lalanine, L-arginine, glycine, L-lysine, L-aspartic acid, Lleucine, L-tyrosine, L-proline, L-threonine, L-histidine, Lcystine, and L-methionine. Each sample has a significantly different amino acid composition at the $95 \%$ confidence level. Based on Figure 1, L-glutamic acid, L-arginine, and L-aspartic acid are the most abundant amino acids in these shallots cultivar. These results are supported by the previous research by Abdelrahman et al. (2020) that in Indonesian shallot, glutamic acid is included in a high amount of amino acids as well as asparagine, serine, histidine, threonine, proline and valine. Glutamic acid itself will taste sour under the dissociated form or in the dipeptide form. However, if this compound binds with Sodium to form Monosodium Glutamate (MSG), it will be detected as an umami taste (Nishimura and Kato 1988).

In this study, L-methionine was detected as the lowest amount of amino acid compared to other amino acids tested. This result was confirmed that by Abdelrahman et al. (2020), who found that tryptophan, methionine, tyrosine, isoleucine, and lysine in low levels. An interesting finding in this study is that the Bauji cultivar has the highest content of 13 amino acids except for L-isoleucine, L-tyrosine, L-proline, and L-methionine. Meanwhile, Lmethionine was only detected in the Bima Brebes bulb. The abundance of specific amino acids in shallot may not significantly affect fresh shallot taste because this fresh bulb is dominant with a pungent sensation. However, reactions may occur if there is a processing process on fresh shallots, such as a frying process that causes certain reactions which involve amino acid compounds.

\section{The diversity of six shallot cultivars based on bulb character and amino acid profile}

Bulb fresh weight of the six cultivars showed in Table 1. The fresh weight of Batu Ijo cultivar was significantly different from the other five cultivars. Batu Ijo has a relatively larger fresh weight per tuber, which is around 1220 grams, as compared to other cultivars with a maximum weight per tuber of only 10 grams (Baswarsiati et al. 2015). This result was supported by previous research (Herlina et al. 2018), Batu Ijo previously named Bali Karet has a low similarity value based on morphological traits compared to other cultivars.

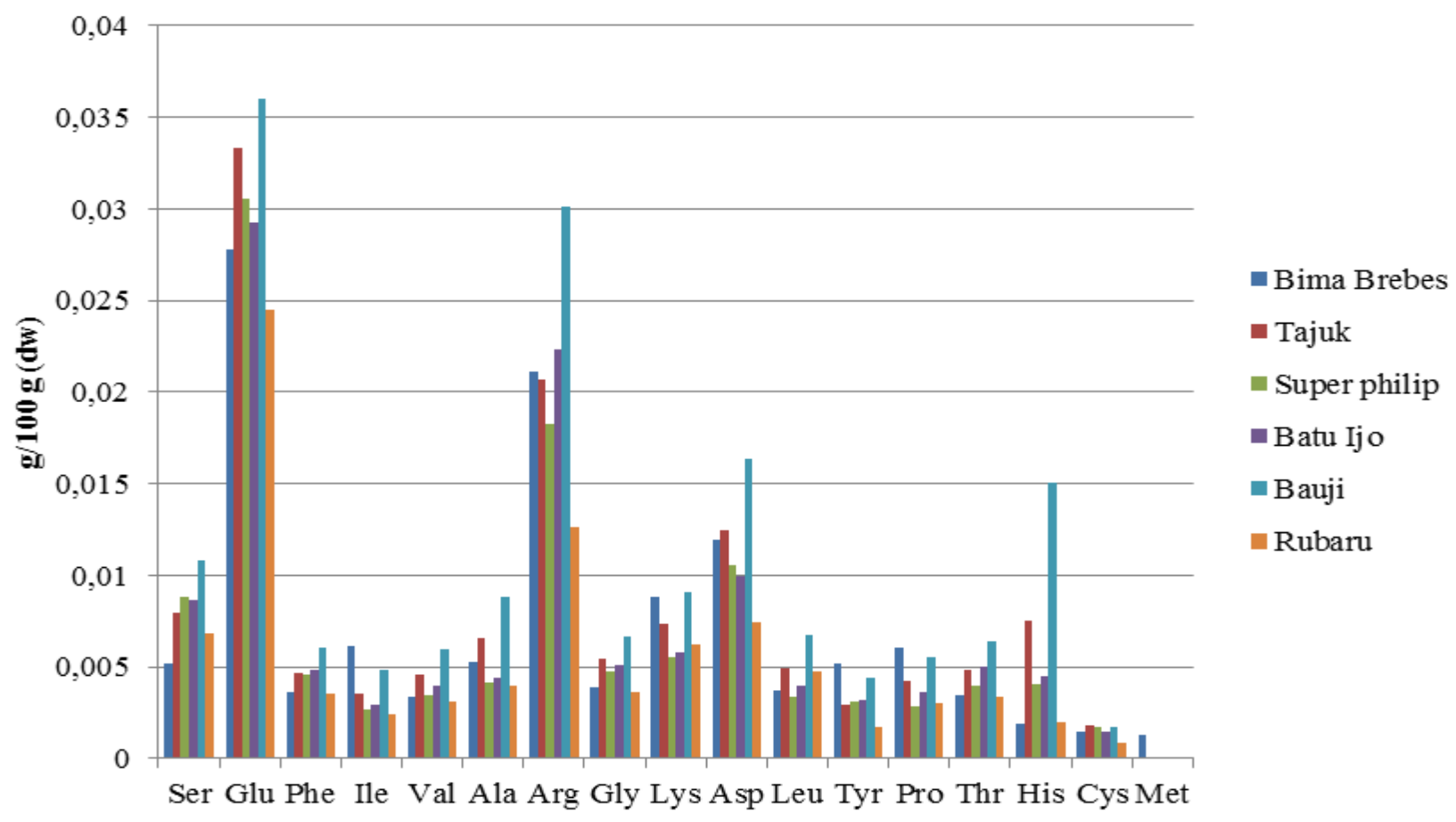

Figure 1. Amino acid profile of six Indonesian shallot cultivars analyzed by using an HPLC instrument 
Table 1. Bulb fresh weight of six Indonesian shallots

\begin{tabular}{ll}
\hline Shallot cultivars & Fresh weight $(\mathrm{g})$ \\
\hline Bima Brebes & $4.36 \pm 1.603 \mathrm{a}$ \\
Batu Ijo & $14.93 \pm 8.879 \mathrm{~b}$ \\
Rubaru & $2.74 \pm 1.093 \mathrm{a}$ \\
Tajuk & $3.62 \pm 1.984 \mathrm{a}$ \\
Bauji & $4.81 \pm 2.302 \mathrm{a}$ \\
Super Philip & $4.41 \pm 1.500 \mathrm{a}$ \\
\hline Note: numbers followed by
\end{tabular}

Note: numbers followed by the same superscript are not significantly different at Tukey post hoc test (0.05)

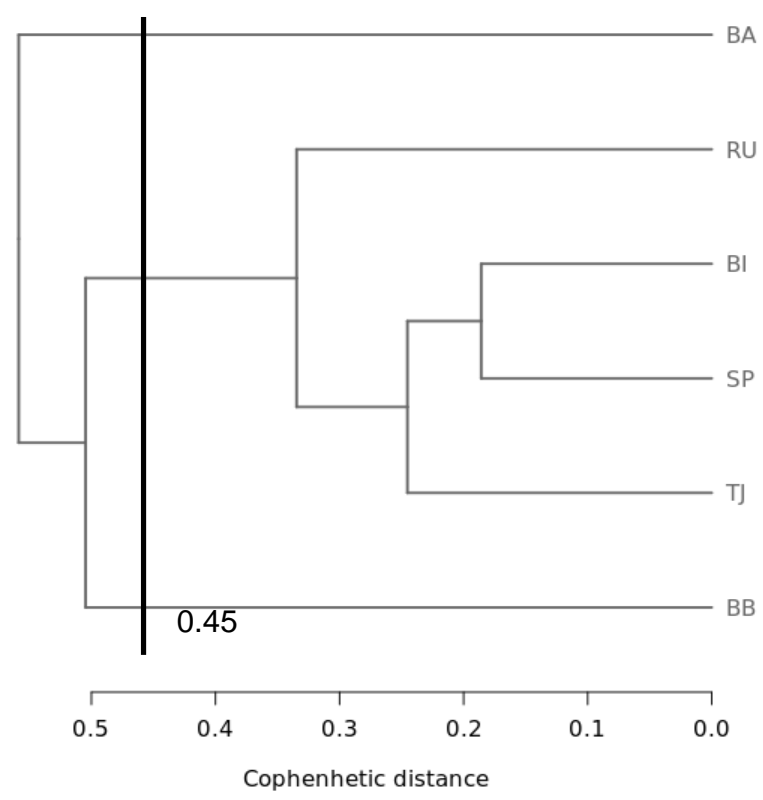

Figure 2. Dendrogram of six shallot cultivars based on amino acid profile. BI: Batu Ijo, TJ: Tajuk, RU: Rubaru, BA: Bauji, SP: Super Philip, BB: Bima Brebes

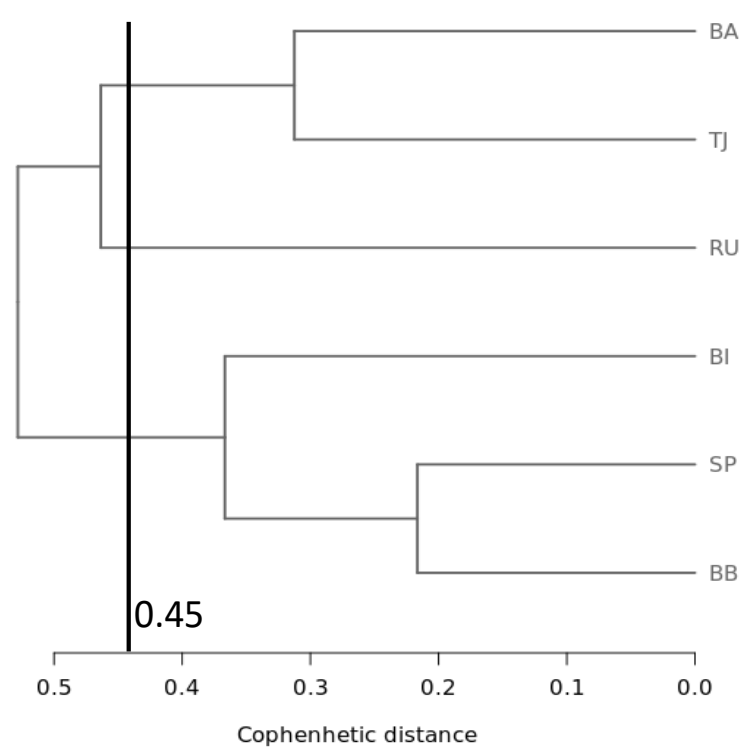

Figure 3. Dendrogram of six shallot cultivars based on its fried shallots' sensory profile (aroma and taste). BA: Bauji, TJ: Tajuk, RU: Rubaru, BI: Batu Ijo, SP: Super Philip, BB: Bima Brebes
The diversity of shallots can be tested using the clustering method. The Gower clustering method was used in this study because the data categories used were varied. The greater value of the cophenetic distance showed the greater genetic differences between the cultivar. In Figure 2 , a dendrogram of six shallot cultivars is shown based on their amino acid profiles. At a cophenetic distance of 0.45 , there are three clusters where the first group only consisted of Bauji cultivar, the second group consisted of Rubaru, Batu Ijo, Super Philip, and Tajuk cultivars, while the third group consisted of Bima Brebes cultivars. The first group is based on the abundance of amino acids L-serin, Lphenylalanine, and glycine in the Bauji cultivar. On the other hand, the third group only consisted of the Bima Brebes cultivar, which was grouped by itself based on the abundance of amino acids L-tyrosine and L-methionine. Meanwhile, the second group consisted of 4 cultivars that had a moderate amount of amino acids than the other two cultivars.

Clustering shallots based on amino acid composition has a different pattern of the bulb fresh weight, indirectly indicating that the amino acid composition has a weak correlation with the morphology trait. This result suggested that a study on amino acid composition is important to determine which varieties are suitable for specific use, since the amino acid composition could not be represented by bulb weight character. This information is important because amino acid composition can affect processing processes that use high temperatures, for example in the Maillard reaction involving amino acids and reducing sugars. For the plants, amino acids are a source of nitrogen, precursors for other secondary metabolites, and can even be used as a preventative for stress (Yang et al. 2020). The flavor precursors of the Allium family are usually amino acid and sulfur-containing compounds, for example, transS-1-propenyl cysteine sulphoxide and S-propyl cysteine sulphoxide on onion (Jones et al. 2004), the biosynthesis of these flavor compounds is closely related to the biosynthesis of amino acids, especially cysteine (Jones et al. 2004). Alliin and glutathione compounds from garlic extract also contain amino acids, and these compounds were found to have a kokumi effect on umami solution (Ueda et al. 1990). From this finding, it is no wonder that Alliums, especially shallots in Indonesia, are used as an Indonesian cooking spice.

\section{The diversity of the six cultivars based on the sensory characteristics of fried shallots}

The sensory characteristics of six fried shallots from different cultivars were obtained through rate-all-that-apply sensory descriptive method on 103 untrained panelists. Figure 3 showed a dendrogram of six cultivars of fried shallots based on sensory characteristics detected by panelists. At a cophenetic distance of 0.45 , there were three groups of fried shallots. The first group consisted of Bauji and Tajuk cultivars, the second group consisted only of Rubaru cultivars, while the third group consisted of Batu Ijo, Super Philip, and Bima Brebes cultivars. 
Table 2. The correlation coefficient of the sensory characteristics of six fried shallots and the amino acid profile of its fresh bulb

\begin{tabular}{|c|c|c|c|c|c|c|c|c|}
\hline Variable & $\begin{array}{l}\text { Brown } \\
\text { color }\end{array}$ & $\begin{array}{c}\text { Fragrant } \\
\text { sulfury aroma }\end{array}$ & $\begin{array}{l}\text { Sweet } \\
\text { aroma }\end{array}$ & $\begin{array}{l}\text { Rancid } \\
\text { aroma }\end{array}$ & $\begin{array}{c}\text { Savory } \\
\text { taste }\end{array}$ & $\begin{array}{c}\text { Sweet } \\
\text { taste }\end{array}$ & $\begin{array}{l}\text { Salty } \\
\text { taste }\end{array}$ & $\begin{array}{c}\text { Bitter } \\
\text { taste }\end{array}$ \\
\hline L-Serine & -0.485 & -0.471 & -0.242 & 0.098 & -0.006 & 0.766 & -0.531 & -0.632 \\
\hline L-Glutamic acid & -0.336 & -0.670 & -0.055 & 0.479 & -0.149 & 0.786 & -0.314 & -0.876 \\
\hline L-Phenylalanine & -0.475 & -0.580 & -0.177 & 0.245 & -0.033 & 0.868 & -0.404 & -0.838 \\
\hline L-Isoleucine & 0.015 & -0.063 & 0.353 & 0.517 & -0.177 & 0.169 & -0.043 & -0.230 \\
\hline L-Valine & -0.661 & -0.770 & -0.328 & 0.554 & -0.358 & 0.680 & -0.415 & -0.825 \\
\hline L-Alanine & -0.635 & -0.766 & -0.260 & 0.763 & -0.524 & 0.509 & -0.416 & -0.720 \\
\hline L-Arginine & -0.345 & -0.454 & 0.042 & 0.347 & -0.015 & 0.833 & -0.270 & -0.822 \\
\hline Glycine & -0.513 & -0.705 & -0.248 & 0.361 & -0.145 & 0.808 & -0.339 & -0.890 \\
\hline L-Lysine & -0.367 & -0.407 & 0.021 & 0.786 & -0.521 & 0.152 & -0.264 & -0.336 \\
\hline L-Aspartic acid & -0.353 & -0.554 & 0.072 & 0.641 & -0.258 & 0.685 & -0.396 & -0.742 \\
\hline L-Leucine & -0.937 & -0.808 & -0.632 & 0.706 & -0.731 & 0.238 & -0.552 & -0.474 \\
\hline L-Tyrosine & 0.186 & 0.069 & 0.567 & 0.301 & 0.140 & 0.489 & -0.084 & -0.366 \\
\hline L-Proline & -0.171 & -0.244 & 0.176 & 0.575 & -0.266 & 0.241 & -0.064 & -0.376 \\
\hline L-Threonine & -0.599 & -0.680 & -0.329 & 0.296 & -0.139 & 0.791 & -0.324 & -0.868 \\
\hline L-Histidine & -0.678 & -0.744 & -0.319 & 0.570 & -0.386 & 0.664 & -0.535 & -0.755 \\
\hline L-Cystine & 0.193 & -0.336 & 0.348 & 0.214 & 0.230 & 0.774 & 0.000 & -0.780 \\
\hline L-Methionine & 0.457 & 0.423 & 0.579 & 0.132 & 0.101 & -0.205 & 0.254 & 0.239 \\
\hline
\end{tabular}

Note: a value coefficient correlations more than 0.80 or less than -0.80 (written in bold) are considered significantly correlated at 0.05 level

The first group was characterized by similar characteristics of the sweet and bitter taste. These two fried shallots tend to be sweet and have a low intensity of bitter taste. Meanwhile, the second group consisted only of the Rubaru cultivar was characterized by a dominant bitter taste. The public favor this cultivar to be commercial fried shallots, but in this study, it was found that Rubaru has a high intensity of bitter taste. Yofananda et al. (2020), in their research, states that bitter taste is a sensory limiting factor in the acceptance of fried shallots, besides the high intensity of rancid aroma. The third group is characterized by a savory taste and fragrant sulfury aroma that was more dominant than the other three cultivars, and these two characteristics are desirable in fried shallots, and according to Yofananda et al. (2020), this indicates that Batu Ijo, Super Philip and Bima Brebes cultivars are potential to become fried shallot products according to consumer perceptions. This information is important for fried shallot producers.

\section{Correlation of amino acid profile of fresh shallots with sensory characteristics of fried shallots}

The correlation between the sensory characteristics of fried shallots and the amino acid profiles of the fresh bulb was determined using the Pearson correlation method. The results were shown in Table 2 . In this study, each of the amino acids such as L-phenylalanine, L-arginine, and glycine had a strong positive correlation (0.868; 0.833 ; 0.808 , respectively) with the sweet taste of fried shallots, meanwhile, L-glutamic acid, L-serine, L-threonine, Laspartic acid, L-cystine and L-valine had the moderate positive correlation $(0.786 ; 0.766 ; 0.791 ; 0.685 ; 0.774$; 0.680 , respectively). According to Nishimura and Kato (1988), L-Phenylalanine in the form of free amino acids will taste bitter. Meanwhile, glycine can be detected as a strong sweet taste. Wong et al. (2008) found that the amino acids glycine and threonine reacted with glucose under heating conditions of $100^{\circ} \mathrm{C}$ for 14 and/or 24 hours become sweet in taste. Meanwhile, L-phenylalanine which reacts with glucose under the same conditions will produce a flowery, butter, and bitter flavor, as well as the taste produced by arginine and glucose, which will produce a bitter taste. Interactions between amino acids can cause these different results or processing conditions to deliver different sensory characteristics.

In this study, the Bauji cultivar had the highest level of L-phenylalanine and, the Pearson correlation showed that this amino acid correlated (0.868) with sweet taste, which is an interesting finding. Further research is needed to determine the metabolite changes of fresh shallots into fried shallots, and chemical compounds of fried shallots in relation to their sensory characteristics. Information on the sensory characteristics of fried shallots from various cultivars is also important for industry players as a reference for the use of cultivars that are more appropriate for the production of fried shallots following the market demands.

In conclusion, based on morphology trait Batu Ijo is significantly different from the other five shallots. Generally, the six shallot cultivars tested are characterized by a high content of glutamic acid, arginine, and aspartic acid. Based on its amino acid profile, the shallot cultivars were divided into three groups, namely Bauji, which was characterized by L-serine, L-phenylalanine, and glycine. Batu Ijo, Tajuk, Super Philip, and Rubaru were put into one group characterized by a moderate level of amino acid content. In contrast, L-tyrosine and L-methionine categorized Bima Brebes into one group. Thus, the characteristics of amino acids on shallot can not be defined by morphology traits only. In addition, the clustering on the taste and aroma of fried shallots was not the same as the amino acid clustering. Based on the sensory characteristics, the fried shallots were divided into three groups, the first group consisted of Bauji and Tajuk cultivars characterized 
by the sweet taste, the second group consisted only of Rubaru cultivars characterized by a bitter taste, while the third group consisted of Batu Ijo, Super Philip, and Bima Brebes cultivars are characterized by a savory taste and fragrant sulfury aroma. Therefore, Batu Ijo, Super Philip, and Bima Brebes might become preferred cultivars for fried shallot products based on their sensory characteristics. This is important information for the diversification of fried shallots.

\section{ACKNOWLEDGEMENTS}

The authors would like to thank the Ministry of Research, Technology, and Higher Education Indonesia for providing research funding through PMDSU scholarship 2017, grant number 136/SP2H/LT/DRPM/IV/2017.

\section{REFERENCES}

Abdelrahman M, Ariyanti NA, Sawada Y, Tsuji F, Hirata S, Hang TTM Okamoto M, Yamada Y, Tsugawa H, Hirai MY, Shigyo M. 2020. Metabolome-based discrimination analysis of shallot landraces and bulb onion cultivars associated with differences in the amino acid and flavonoid profiles. Molecules 25 (22): 5300. DOI: 10.3390/molecules25225300

Ariyanti NA, Torikai K, Kirana RP, Hirata S, Sulistyaningsih E, Ito S, Yamauchi N, Kobayashi N, Shigyo M. 2018. Comparative study on phytochemical variation in Japanese $F_{1}$ varieties of bulb onions and South-East Asian shallot landraces. Hort J 87 (1): 63-72. DOI: 10.2503/hortj.OKD-066

Baswarsiati, Sudaryono T, Andri KB, Purnomo S. 2015. Pengembangan varietas bawang merah potensial dari Jawa Timur. In: Djatnika I, Syah MJA, Widiastoety D, Yufdy MP, Prabawati S, Pratikno S, Luthfiyah O (eds) Inovasi Holtikultura. IAARD Press, Jakarta. [Indonesian]

Chang C, Wu G, Zhang H, Jin Q, Wang X. 2020. Deep-fried flavor: Characteristics, formation mechanisms, and influencing factors. Crit Rev Food Sci Nutr 60 (9): 1496-1514. DOI: 10.1080/10408398.2019.1575792.

Ferioli F, D'Antuono LF. 2015. Evaluation of phenolics and cysteine sulfoxides in local onion and shallot germplasm from Italy and Ukraine. Genet Resour Crop Evol 63: 601-614. DOI: 10.1007/s10722-015-0270-2.

Franklin LM, Mitchell AE. 2019. Review of the sensory and chemical characteristics of almond (Prunus dulcis) flavor. J Agric Food Chem 67: 2743-2753. DOI: 10.1021/acs.jafc.8b06606.

Galingging R, Sobir, Aisyah S, Maharijaya A. 2018. GC-MS Profiling of volatile compounds from fifteen different varieties of Indonesian shallot grown in tidal swampland. Rayasan J Chem 11 (4): 575-581. DOI: 10.3178 no8/rjc.2018.1123001.

Herlina L, Reflinur, Nugroho K, Terryana RT, Sobir, Maharijaya, Wiyono S. 2018. Genetic diversity analysis using resistance gene analog-based markers to support morphological characterization of shallots. Jurnal AgroBiogen 14 (2): 65-74. DOI: 10.21082/jbio.v14n2.2018.p65-74.

Herlina L, Reflinur, Sobir, Maharijaya A, Wiyono S, Istiaji B. 2019a. Genetic diversity of Indonesian shallots based on bulb-tunic patterns and morphological characters. Indon J Agric Sci 20 (1): 19-28. DOI: 10.21082/ijas.v20n1.2019.p19-28.

Herlina L, Reflinur, Sobir, Maharijaya A, Wiyono S. 2019b. The genetic diversity and population structure of shallots (Allium cepa var. aggregatum) in Indonesia based on $\mathrm{R}$ gene-derived markers. Biodiversitas 20 (3): 696-703. DOI: 10.13057/biodiv/d200312.

Jones MG, Hughes J, Tregova A, Milne J, Tomsett AB, Collin HA. 2004. Biosynthesis of flavor precursors of onion and garlic. J Exp Bot 55 (404): 1903-1918. DOI: 10.1093/jxb/erh138.

Major N, Ban SG, Ulrić B, Ban D, Dumičić G, Perković J. 2018. Morphological and biochemical diversity of shallot landraces preserved along the Croatian coast. Front Plant Sci 9: 1749. DOI: 10.3389/fpls.2018.01749.

Nishimura T, Kato H. 1988. Taste of free amino acids and peptides. Food Rev Int 4 (2): 175-194. DOI: 10.1080/87559128809540828.

Sari V, Miftahudin, Sobir. 2017. Genetic diversity of shallot (Allium cepa L.) based on morphological and ISSR markers. J Agron Indonesia 45 (2): 175-181. DOI: 10.24831 jai.v45i2.11665.

Soininen TH, Jukarainen N, Auriola, SOK, Julkunen-Tiitto R, Karjalainen R, Vepsäläinen JJ. 2014. Quantitative metabolite profiling of edible onion species by NMR and HPLC-MS. Food Chem 165: 499-505. DOI: 10.1016/j.foodchem.2014.05.132.

Sung J, Suh JH, Chambers AH, Crane J, Wang Y. 2019. Relationship between sensory attributes and chemical composition of different mango cultivars. J Agric Food Chem. 67: 5177-5188. DOI: 10.1021/acs.jafc.9b01018.

Ueda Y, Sakaguchi M, Hirayama K, Miyajima R, Kimizuka A. 1990. Characteristic flavor constituents in water extract of garlic. Agric Biol Chem 54 (1): 163-169. DOI: 10.1080/00021369.1990.10869909.

Vu QH, Hang TTM, Yaguchi S, Ono Y, Pham TMP, Yamauchi N, Shigyo M. 2013. Assessment of biochemical and antioxidant diversities in shallot germplasm collection from Vietnam and its surrounding countries. Genet Resour Crop Evol 60: 1297-1312. DOI: 10.1007/s10722-012-9920-9.

Waehrens SS, Zhang S, Hedelund PI, Petersen MA, Byerne DV. 2016. Application of the fast sensory method Rate-All-That-Apply in chocolate quality control compared with DHS-GC-MS. Int J Food Sci Technol 51: 1877-1887. DOI: 10.1111/ijfs.13161.

Wakamatsu J, Stark TD, Hofmann T. 2016. Taste-active Maillard reaction products in roasted garlic (Allium sativum). J Agric Food Chem 64 (29): 5845-5854. DOI: 10.1021/acs.jafc.6b02396.

Waters Corporation. 2012. Amino acid analysis Application notebook. https://www.waters.com/webassets/cms/library/docs/720006130en.pd f.

Wong KH, Aziz SA, Mohamed S. 2008. Sensory aroma from Maillard reaction of individual and combinations of amino acids with glucose in acidic conditions. Int $\mathbf{J}$ Food Sci Technol 43: 1512-1519. DOI: 10.1111/j.1365-2621.2006.01445.x.

Yang Q, Zhao D, Liu Q. 2020. Connections between amino acid metabolism in plants: Lysine as an example. Front Plant Sci 11: 928. DOI: $10.3389 /$ fpls.2020.00928.

Yofananda O, Wijaya CH, Lioe HN, Sobir. 2020. Fried shallot quality: Perception and differentiation. Curr Res Nutr Food Sci J 8 (1): 97106. DOI: 10.12944/CRNFSJ.8.1.09. 